\title{
Farmers' Attitude On Different Watershed Management Practices: A Case of Tende and Kibuon Catchments in South West, Kenya
}

\author{
Catherine Athanasa Mulwale *, Prof. Evans Abenga Basweti**, Dr. Washington Adede Ochola*** and Prof.

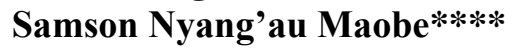

*Department of Agricultural Education and Extension, Kisii University, Kenya)

*(cmulwale@yahoo.com, Mobile telephone number- 254716796001)

P.O Box 395- 40300 Homa Bay, Kenya

** (Department of Agricultural Education and Extension, Kisii University, Kenya)

*** (Department of Agricultural Education and Extension, Kisii University, Kenya)

**** (Department of Agricultural Education and Extension, Kisii University, Kenya)

DOI: 10.29322/IJSRP.10.11.2020.p10740

http://dx.doi.org/10.29322/IJSRP.10.11.2020.p10740

\begin{abstract}
Watershed degradation is an example of natural resource degradation that affects environment and food security negatively. Integrated Land and Watershed Management Project in Kibuon and Tende catchments (ILWMKTP) ran from 2009 to 2014. The programme focused on reduction of degradation by using soil and water conservation practices. The survey was carried out in Kisii, Nyamira and Homa Bay Counties which were purposively selected since they implemented the project. The study was an ex post facto research design which used cross sectional survey approach that applied qualitative and quantitative data collection procedures. The survey targeted a population of 9,475 respondents who implemented ILWMKTP project while the accessible population was 370 farmers who were proportionately selected through simple random method. The survey used a questionnaire and an interview schedule to collect data from farmers and key informants. A research tool was used to gather data on attitude farmers' in terms of practices used to control watershed degradation. Data analysis was done using SPSS version 25. There were significant differences in levels of positive attitude on watershed management practices. Responses captured were rated on a five point likert scale and frequencies were run for respondents who agreed on positive statements on the practices and their percentages were between fifty one and seventy one percent. This implied that respondents had different levels of positive attitude on watershed management practices in the catchments.
\end{abstract}

Index Terms- Attitude, watershed, practices and management

\section{INTRODUCTION}

Water and soil are key in economic development of any nation through agricultural production (Heiner, Shames \& Spiegel, 2016). Globally, watershed degradation has become severe affecting more than 20 percent of agricultural land, 30 percent of forested and 10 percent of grassland. Affected areas range between 20 percent to 50 percent of land in Sub Saharan Africa inhabited by 200 million people (Tamene, IKindu, Woldearegay \& Aberra, 2014). Watershed degradation is the most serious natural resource degradation affecting environment and socio-economic factors (Atnafe, Ahmed \& Adane, 2015). It threatens food security making watersheds prone to climate change variability including poverty (Mesfin, 2010; Ibido, 2015; Kieti, Kauti \& Kisangau, 2016). Kibuon and Tende catchments are on Eastern side of Lake Victoria in South West Kenya and were characterized with degradation which contributed to less water base flow and enhanced poverty. Benefits of watershed management cannot be overstated, therefore Integrated Land and Watershed Management Project in the catchments was implemented from 2009 to 2014 to enhance land productivity and water base flow in the in the two rivers. The agricultural extension programme planning and implementation interventions used an Integrated Project Extension Approach in ILWMKTP to disseminate watershed management practices. The approach is the best for dissemination of soil and water conservation practices among smallholder farmers who are resource limited.

\section{Literature Review}

Global Degradation of Watersheds

Most developing countries in the world are keen on watershed management because of its negative effect on food security (Swallow, Onyango \& Meinzen-dick, 2008). Watershed degradation and limited land resources have a negative impact on systems used in food production expected to feed a world population of 9 billion people by 2050 (Manuelli, Hofer, \& Vita, 2014). Soil erosion contributes to watershed degradation which reflects in a decline in food productivity (Blinkov, Kostadinov \& Marinov, 2013).

\section{Degradation of Watersheds in the Tropics}

Watershed degradation is an economic constraint that affects livelihoods in many nations. Its management in Ethiopia enhances effective use of natural and social capitals in the Country (Tiki, Kewessa \& Wudneh, 2016). According to Mondal, Singh, Singh, Singh and Kumar, (2013), Indian watershed projects address protection of natural resources to increase production. Profitability is crucial in conservation of watersheds because benefits from some of the practices are not felt immediately (Darghouth et al., 
2008). According to Mesfin, (2010) the decision to implement practice watershed management starts with accepting erosion as an issue since some of the structures take between 5-15 years before their effects are felt. Their uptake is determined by social and economic factors, and demographic factors (Ibido, 2015 \& Adjaye, 2008).

\section{Degradation of Watersheds in Kenya}

Watershed degradation in Kenya is caused by high population, over-use of natural resources, climate variability and release of pollutants in the environment (GoK, 2014; Kieti, Kauti \& Kisangau, 2016; Gunya, 2009). Degradation reduces forest cover despite their products being used by eight percent of Kenyans (Swallow \& Meinzen-dick, 2008 \& Lake Victoria South Catchment Area, 2012). Like many countries, Kenya is faced with inter-related constraints in terms of limited resources, food insecurity and competition for natural resources due to watershed degradation (Heiner, K. , Shames, S. \& Spiegel, 2016). It affects well- being of watersheds which provides goods and services to communities (Kieti et al., 2016). The country is experiencing faster depletion of natural resources than they are replenished for example around Lake Naivasha there is water scarcity due to water over use by horticulture and industries in the area (World Bank, 2016). Watershed degradation results in low productivity of watersheds due to human activities (Mainuri \& Owino, 2016).

\section{Farmers' Attitude on Watershed Management Practices promoted in the Catchments}

Farmers' attitude plays a major role in uptake of watershed management practices and they may choose to take up the practices or not. Positive attitude contributes to high uptake of watershed management practices (Hosseini, Daryaei, \& Rahnama, 2014). Farmers' positive attitude in terms of water resource management and behavioral change contribute to enhanced responses on watershed conservation and enhance investment in the practices (Pino, Toma, Rizzo, Miglietta \& Peluso, 2017). Their positive attitude, beliefs and readiness to change increases uptake of the practices (Wisdom \& Chor (2013). Positive environmental attitude encourages farmers to take up watershed management practices as they anticipate positive change (Prokopy, Towery \& Babin, 2013). The positive attitude towards land degradation, benefits of soil and water conservation practices and increased land productivity enhance uptake of the practices (Kipngeno, 2007). Farmers with positive attitude towards alleviation of soil erosion on their farms take up soil and water conservation practices to reduce the erosion and improve productivity (Kerse, 2018). Further, attitude shapes the farmers' opinion in terms of uptake of watershed management practices. Positive attitude is significant in uptake of practices and maintenance of degraded watersheds (Wolka \& Negash, 2014). A study in Iran showed that farmers' positive attitude on uptake of watershed practices and acceptance of soil erosion as a major constraint contributed greatly to uptake of the practices (Hosseini et al., 2014). Support from the Government and private organizations motivated development of a positive attitude among farmers to take up soil and water conservation practices leading to enhanced uptake of the practices (Zerssa, Bezabih \& Dinkecha, 2017). High rate of uptake for soil and water conservation practices is enhanced by ease of use, low cost and their effectiveness among farmers with positive attitude (Junge, Deji, Abaidoo, Chikoye \& Stahr, 2009). In addition, most farmers who take up soil and water conservation practices show interest in taking up the practices. Short term impact, positive attitude of the practices and benefits increase the rate of uptake of the practices among farmers (Mithun, 2013). They can take up many practices as long as benefits are higher than their cost of implementation (Kipngeno, 2007).

\section{Geographical Description of the Study Area}

\section{IDENTIFY, RESEARCH AND COLLECT IDEA}

The survey was conducted in rivers Kibuon and Tende catchments which cover Kisii, Nyamira and Homa Bay Counties in South West Kenya. The area was purposively selected because of having implemented a project on watershed management. The study area receives rain two times in per year; Homa Bay County is located between $\mathrm{LM}_{1}$ to $\mathrm{LM}_{4}$ agro ecological zones and receives 450-1000 mm of rain per year. Kisii County lies between $\mathrm{LH}_{1}$ to $\mathrm{LH}_{3}$ agro ecological zones and receives rainfall range between $1500 \mathrm{~mm}$ to $2000 \mathrm{~mm}$ per year while Nyamira County is situated between $\mathrm{LH}_{1}$ to $\mathrm{UM}_{2}$ agro ecological zones and receives between $1500 \mathrm{~mm}$ to $2000 \mathrm{~mm}$ of rain per year. The catchments run from Nyamira, Kisii Counties through Homa Bay County into Lake Victoria. Kibuon catchment was divided in 3 sub catchments; Kibuon (K1, Kabondo (K2) and Kasipul (K3) sub catchments while Tende catchment was divided in three sub catchments namely; Tende (T1), Isanta T2 and Mogusii (T3) sub catchments. Tende (T1) and Kibuon (K1) are situated in the upper part of the two catchments. Kibuon (K2) and Tende (T2) are found in middle catchments while Kibuon (K3) and Tende (T3) are situated in the lower parts of both catchments.

\section{Research Design}

The design was an ex post facto research design with cross sectional survey approach which combined qualitative and quantitative data collection methods. Ex post facto is a systematic empirical enquiry without alteration of independent variables since they had already taken place (Manjunath, 2014). Both primary and secondary data were utilized. Primary data was gathered from respondents and key informants using interview schedules and questionnaires respectively. Additional data was collected through observation. Reports, policy documents and books from Government institutions provided secondary data. The design was suitable because the farmers interviewed had equal opportunities to participate in the research since they implemented the project and conditions were not changed during the interview.

\section{Population of the Study}

The target population was 68 CBOs that participated in implementation of ILWMKTP project with a membership of 9,475 farmers in the project area (Ndeda, 2014). The accessible population was 370 members of 34 CBOs. 


\subsection{Sample Size and the Sampling Techniques}

The research area was selected purposively because it implemented a project on watershed management. Proportionate multiplestage cluster sampling method was used and the study area divided into sub catchments based on the area where the project was implemented and each sub catchment was represented by a number of CBO members. Through proportionate simple random sampling, 50 per cent of the CBOs were selected for the survey. Simple random sampling method was used to get respondents proportionately in every CBO. From 68 CBOs, 34 CBOs were systematically selected each member was selected through simple random sampling procedures. A sample size table by Krejcie and Morgan (1970) in a research paper by Hashim, (2010) recommends a sample size of 370 people from a population of 10,000 people. Nine staff who participated in implementation of the project were interviewed and 370 respondents who were distributed to each sub catchment proportionately were also interviewed.

\section{Instrumentation}

The study applied interview schedule and questionnaire to respondents and key informants respectively to gather data. A research tool was developed to examine respondents' attitude on watershed management practices. This ensured that data collected met the objective of the study. The study also used observation to gather additional data. Data collected was generalized to a wider area although care and more research needed to be conducted since there are different factors which contribute to uptake of watershed management practices in different areas.

\section{Data to be collected}

Data was collected from respondents and key informants from both Kibuon and Tende catchments. The data gathered was on general characteristics of respondents and farmers' attitude on watershed management practices promoted in the catchments.

\section{Data Collection Procedures}

Through Kisii University, a research permit was sought from National Commission of Science, Technology and Innovation (NACOSTI). Agriculture Department in the study area was informed and data was collected from respondents through face to face interview. The research utilized primary and secondary data which was collected from books, journals, reports, policy documents and research papers. Secondary data collected was complemented by data from face to face interview that was conducted in the sub catchments. Data from the farmers and extension staff was triangulated to inform conclusions that were drawn.

\section{Data Analysis}

Quantitative data was analyzed using statistical package for social sciences version 25 while qualitative data was dummy coded and analyzed using SPSS also. Descriptive statistics was used to determine frequencies, means and standard deviations among sub catchments in terms of watershed management practices. For inferential statistics, ANOVA was used to compare means in sub catchments on watershed management practices. Tukey post hoc determined significant differences on watershed management practices. The results were rated on a 5 point likert scale where 1 represented strongly disagree, 2 was disagree, 3 was neutral, 4 was agree and 5 represented strongly agree. Level of significance for inferential statistics was set at $0.05 \%$ (Table 3 ).

Table 1: A Summary of Data Analyses for the Hypothesis

\begin{tabular}{|c|c|c|c|}
\hline Hypothesis & Independent variables & Dependent variable & Statistical method \\
\hline $\begin{array}{l}\mathrm{H}_{01} \text { There is no statistically significant } \\
\text { difference in farmers' attitude on watershed } \\
\text { management practices promoted in the } \\
\text { catchments. }\end{array}$ & -Attitude & $\begin{array}{l}\text {-Terracing } \\
\text {-Cover cropping } \\
\text {-Grass } \\
\text { establishment } \\
\text { Agro forestry }\end{array}$ & $\begin{array}{l}\text { ANOVA, Tukey post hoc } \\
\text { test, frequencies, mean, } \\
\text { standard deviations were } \\
\text { used }\end{array}$ \\
\hline
\end{tabular}

\section{General Respondents' Characteristics}

\section{RESULTS AND DISCUSSIONS}

\section{Gender of the Respondents}

The study interviewed 370 respondents who constituted by 63.2 percent men and 36.8 percent women. Most of the project implementers (234) out of 370 were men while 136 were women. Many women participated in biological and alternative economic enterprises that were not labour intensive to manage for example poultry production, goat rearing and fish farming in the catchments. Decisions on land use were made by men who also provided labour for tedious work in terms of terraces construction. Men were expected to motivate women positively towards watershed management practices and engage them in field activities through provision of labour. These findings agreed with a research report by Wagayehu and Lars (2015) in their study on adoption of soil and water conservation measures which established that although men were heads of households and responsible for decision making on farm activities, women provided primary labour. Increase in labour requirements in soil and water conservation activities is achieved through involvement of women in farm activities to control soil erosion by implementing decisions made by men (Tennyson, 2005). Promotion of gender participation by FAO in activities in watershed programmes and their direct involvement has been successful through provision of labour and skills in uptake of practices in watersheds thereby increasing uptake rate (Table 4).

Table 2: Gender of the Respondents

\begin{tabular}{lll}
\hline Gender & Frequency & Percentage
\end{tabular}




\begin{tabular}{lll}
\hline 0 (Male) & 234 & 63.2 \\
1 (Female) & 136 & 36.8 \\
Total & 370 & 100 \\
\hline
\end{tabular}

Age of Respondents

Most of the farmers interviewed (74.3 percent) were above 40 years of age and majority were between 50-60 years old while 5.7 percent were below 40 years of age. The lowest percentage $(1.4 \%)$ was represented by respondents who were below 30 yearsout of the total sample size (Table 5). Data analysis indicated that participation in watershed management technologies was influenced by age. Land was valued by older people compared to young people therefore they made the decision to participate in soil and water conservation activities to conserve the watersheds which improved soil fertility and translated in increased productivity. This is in line with findings by Bayard, Jolly and Shannon (2006) in their study on adoption and management of soil conservation practices in Haiti which indicated that age influenced participation in soil and water conservation whereby uptake increased with progression in age which was also reported by (Sheikh, Redzuan, Samah, \& Ahmad, 2014) in their study on factors influencing farmers' participation in water management.

Table 3: Age Ranges for Respondents

\begin{tabular}{lll}
\hline Age ranges & Frequency & Percentage \\
\hline $20-30$ years & 5 & 1.4 \\
30-40 years & 16 & 4.3 \\
40-50 years & 58 & 15.7 \\
$50-60$ years & 221 & 59.7 \\
Above 60 years & 70 & 18.9 \\
Total & 370 & 100 \\
\hline
\end{tabular}

\section{Marital Status}

Many farmers interviewed were married (99.5 percent). Married men had more labour for soil and water conservation practices implementation provided by wives and children compared to those who were not married. The project worked with men, women and youth who were either married or single (Table 6). Men made decisions on which soil and water conservation practices to be taken up on their farms while women and youth implemented decisions made by providing family labour. They participated in watershed management to restore productivity in maize, milk and forage for improved household income through enhanced watershed management. Similar observations were reported by Rehema (2014) in her study on factors influencing adoption of soil conservation measures in Tanzania which established that married women participated in soil conservation to increase family income although decisions on practices were made by men. German, Mansoor, Alemu, Getachew, Mazengia, and Stroud, (2006) confirmed in their study on participatory integrated watershed management that successful watershed management needed to address constraints affecting both women and youth in relation to decision made by men in the catchment for active participation by family members. There was need to consider female domains like reduced areas under agroforestry reflected in less wood fuel and how land use practices affected livelihoods of the people living in catchments.

Table 4: Marital Status

\begin{tabular}{lll}
\hline Marital status & Frequency & Percentage \\
\hline Married & 368 & 99.5 \\
Not married & 2 & .5 \\
Total & 370 & 100 \\
\hline
\end{tabular}

Farmer's Level of Education

Majority of the respondents had primary level of education followed by secondary level while the least percentage (1.4 percent) of respondents attained tertiary level of education (Table 7). This implied that farmers were able to participate and implement soil conservation practices as long as they had basic education and were taken through the trainings which was similarly reported by Lesch and Wachenheim (2014) in their study on factors influencing conservation practice adoption in Agriculture which reported that education was inconsistent in participation of respondents in soil and water conservation practices. Uptake of watershed management technologies increases with proper trainings regardless of education level which does not agree with findings by Sheikh et al. (2014) in their study on factors influencing farmers' participation in water management who found out that education influenced implementation of soil and water conservation technologies in the catchment.

Table 5: Farmers' Level of Education

\begin{tabular}{lll}
\hline Age ranges & Frequency & Percentage \\
\hline Not gone to school & 33 & 8.9 \\
Primary level & 193 & 52.2 \\
Secondary level & 130 & 35.1 \\
Middle level college & 9 & 2.4 \\
Tertiary & 5 & 1.4 \\
Total & 370 & 100 \\
\hline
\end{tabular}




\section{Size of Family}

There were varied family sizes whereby majority had more than 5 family members ( 70 percent), followed by 5 members $(23.8$ percent) and the rest had between 2- 4 family members (Table 8). Many households provided labour needed for implementation of watershed management practices in the catchments which did not agree with a study by Tadesse and Belay (2004) on factors influencing adoption of soil conservation measures in Southern Ethiopia which established that family size affected participation in watershed management practices negatively. High number of households capitalized on short term benefits and would not consider participating in soil conservation whose benefits are long term. Similar findings were reported by Mutuyimana (2015) in her findings on effects of integrated soil and water management on livelihoods which reported family size being important for active participation by farmers in soil and water conservation.

Table 6: Family Size for Respondents

\begin{tabular}{lll}
\hline Number of family members & Frequency & Percentage \\
\hline 2 & 2 & .5 \\
3 & 5 & 1.4 \\
4 & 16 & 4.3 \\
5 & 88 & 23.8 \\
Above 5 & 259 & 70 \\
Total & 370 & 100 \\
\hline
\end{tabular}

\section{Size of Land}

Sizes of land ranged between $1 / 2$ an acre to more than one acre. Half of the respondents (49.7 percent) owned more than one acre, thirty nine point nine percent (39.9 percent) owned one acre and 10.8 percent had less than one acre of land (Table 9). Most of the respondents who implemented Integrated Land and Watershed Management Project in Tende and Kibuon had more than 1 acre of land because some of the practices required more space for their construction while those with smaller pieces of land put one retention ditch on the upper part of their farms and invested in cover crops and agroforestry along the fence. These findings were also reported by Tadesse and Belay (2004) on factors influencing adoption of soil conservation measures in Southern Ethiopia who reported size of land being positive and significantly influenced uptake of soil conservation technologies. Smaller sizes of land restricted implementation of physical technologies which agreed with findings by Mutuyimana (2015) in effects of integrated soil and water management on livelihoods in Rwanda which established that size of land affected uptake of soil and water conservation technologies.

Table 7: Size of Land

\begin{tabular}{lll}
\hline Acreages & Frequency & Percentage \\
\hline $1 / 2$ acre & 10 & 2.7 \\
$3 / 4$ & 30 & 8.1 \\
1 acre & 146 & 39.5 \\
More than one acre & 184 & 49.7 \\
Total & 370 & 100 \\
\hline
\end{tabular}

\section{FARMERS' ATTITUDE ON WATERSHED MANAGEMENT PRACTICES}

Attitude towards watershed management practices was determined on a five point likert scale in which 1 represented strongly disagree, 2 was disagree, 3 was neutral, 4 was agree while 5 represented strongly agree. Data was subjected to ANOVA to compare means, descriptive statistics determined frequencies, means and standard deviations while Tukey post hoc was used to determine significant differences. Responses rated on a 5 point likert scale were analyzed, discussed and presented in a frequency, mean and standard deviations, ANOVA and Tukey post hoc tables.

Productivity is Reducing because of Soil Erosion

The following means and standard deviations were achieved; Kibuon K2 had a mean of 4.30 and standard deviation of 0.709 , Kibuon K1 had a mean of 4.20 with a standard deviation of 1.082, Tende T1 had a mean of 4.01 with a standard deviation of .595, Mogusii T3 had a mean of 4.00 with a standard of .795. This was followed by Kasipul K3 with a mean of 3.94 and standard deviation of .785. Sub catchment with the least mean was Isanta T2 with a mean of 3.83 and .601 standard deviation (Table 157).

Table 8: Means on Productivity Reducing because of Soil Erosion

\begin{tabular}{llll}
\hline Sub catchment & $\mathrm{N}$ & Mean & Standard deviation \\
\hline Kibuon K1 & 15 & 4.20 & 1.082 \\
Kibuon K2 & 70 & 4.30 & .709 \\
Kasipul K3 & 51 & 3.94 & .785 \\
Tende T1 & 148 & 4.01 & .595 \\
Isanta T2 & 47 & 3.83 & .601 \\
Mogusii T3 & 39 & 4.00 & .795 \\
Total & 370 & 4.04 & .703 \\
\hline
\end{tabular}


ANOVA results showed that there were significant difference at $\mathrm{F}=3.277, \mathrm{p}=.007$ on the level at which productivity was reducing due to soil erosion in different sub catchments. This indicated that sub catchments were significantly different which implied that attitude on soil erosion reducing productivity varied from one sub catchment to the other (Table 158). Multiple comparisons showed that Kibuon K2 and Isanta T2 had significant mean difference of .470 significant at .005 which indicated that scores on productivity reducing due to soil erosion varied in Kibuon K2 and Isanta T2.

Table 9: ANOVA Results on Productivity Reducing because of Soil Erosion

\begin{tabular}{lllll}
\hline Variations & Sum of squares & DF & Mean square & F \\
\hline Between Groups & 7.857 & 5 & 1.571 & 3.277 \\
Within Groups & 174.535 & 364 & .479 & .007 \\
Total & 182.392 & 369 & & \\
\hline
\end{tabular}

Through Tukey post hoc, Isanta T2 was similar to Kasipul K3, Mogusii T3, Tende T1 and Kibuon K1 and significantly different from Kibuon K2. Many respondents in Kibuon K2 reported productivity reducing due to soil erosion followed by Kibuon K1, Tende T1, Mogusii T3, Kasipul K3 and Isanta T2. Kasipul K3, Mogusii T3, Tende T1 and Kibuon K1 were not significantly different from any sub catchment (Table 159).

Table 10: Tukey Post Hoc Analysis Results on Productivity Reducing because of Soil Erosion

\begin{tabular}{llll}
\hline Sub catchment & $\mathrm{N}$ & 1 & 2 \\
\hline Isanta T2 & 47 & 3.83 & 3.94 \\
Kasipul K3 & 51 & 3.94 & 4.00 \\
Mogusii T3 & 39 & 4.00 & 4.01 \\
Tende T1 & 148 & 4.01 & 4.20 \\
Kibuon K1 & 15 & 4.20 & 4.30 \\
Kibuon K2 & 70 & & .203 \\
Significant & & .174 & \\
\hline
\end{tabular}

A high mean value (4.30) of respondents from Kibuon K2 reported productivity reducing because of soil erosion. Kibuon K1 followed closely with a mean difference of 3.20. Tende (mean- 4.01) was third followed by Mogusii T3 (mean- 4.0), Kasipul K3 (3.94) and lastly Isanta T2 (mean of 3.83). Most means were above 4.00 an indication that the respondents were aware that productivity was reducing due to soil erosion which was an indication of positive attitude towards watershed management practices promoted in the catchments. The positive attitude encouraged implementation of soil conservation practices improving on productivity. Analyzed data had an average mean running from 3.83 to 4.30 which indicated that many respondents had a positive attitude towards watershed management practices because of soil erosion which was confirmed by Worku and Tripathi (2015) in their research on watershed management in Highlands of Ethiopia which reported that land degradation, soil erosion and deforestation have contributed to reducing productivity and food shortage in Ethiopia. These findings were also reported by Abebe (2018) in his study on impact of soil and water conservation for improved agricultural production in Ethiopia who reported annual yield in Ethiopia was decreasing due to soil erosion and soil fertility due to absence of soil conservation practice.

\section{Absence of Soil Conservation Practices on a Farm Contributes to Low Yields}

Data gathered was subjected to the descriptive statistics and various means and standard deviations achieved; Kibuon K2 had a mean of 4.04 with a standard deviation of 1.060, Isanta T2 had a mean of 3.77 with a standard deviation of .520, Kasipul K3 had a mean of 3.75 with a standard deviation of .997 , Mogusii T3 had a mean of 3.67 with a standard deviation of .662 and Tende T1 had a mean of 3.62 and standard deviation of .654. Kibuon K1 had a mean of 3.47 and a standard deviation of 1.060 (Table 160). Table 11: Means on Absence of Soil Conservation Practices on a Farm Contributes to Low Yields

\begin{tabular}{llll}
\hline Sub catchment & $\mathrm{N}$ & Mean & Standard deviation \\
\hline Kibuon K1 & 15 & 3.47 & 1.060 \\
Kibuon K2 & 70 & 4.04 & .731 \\
Kasipul K3 & 51 & 3.75 & .997 \\
Tende T1 & 148 & 3.62 & .654 \\
Isanta T2 & 47 & 3.77 & .520 \\
Mogusii T3 & 39 & 3.67 & .662 \\
Total & 370 & 3.74 & .744 \\
\hline
\end{tabular}

There were significant differences at $\mathrm{F}=3.692, \mathrm{p}=.003$ through ANOVA on the levels at which absence of soil conservation technologies contributed to low yields in different sub catchments (Table 161). Multiple comparisons showed Kibuon K2 and Tende T1 had significant mean difference (mean difference .421, significant at .001) which implied that respondents in the two sub catchments scored differently on absence of conservation technologies contributing to low yields.

Table 12: ANOVA Results on Absence of Soil Conservation Practices Contributes to Low Yields

\begin{tabular}{llllll}
\hline Variations & Sum of Squares & DF & Mean Square & F & Sig. \\
\hline
\end{tabular}




\begin{tabular}{lllll}
\hline Between Groups & 9.849 & 5 & 1.970 & 3.692 \\
Within Groups & 194.194 & 364 & .534 & .003 \\
Total & 204.043 & 369 & & \\
\hline
\end{tabular}

Homogenous sub sets displayed results in two columns. Kibuon K1 reported less on absence of soil conservation technologies contributing to low yields in comparison with Tende T1, Mogusii T3, Kasipul K3 and Isanta T2. It was significantly different from Kibuon K2 which reported more absence of soil conservation technologies contributing to reduced yields. Tende T1,

Mogusii T3, Kasipul K3 and Isanta were not significantly different from any sub catchment (Table 162).

Table 13: Tukey Post Hoc Results on Absence of Soil Conservation Practices Contributing to Low Yields

\begin{tabular}{llll}
\hline Sub catchment & $\mathrm{N}$ & 1 & 2 \\
\hline Kibuon K1 & 15 & 3.47 & 3.62 \\
Tende T1 & 148 & 3.62 & 3.67 \\
Mogusii T3 & 39 & 3.67 & 3.75 \\
Kasipul K3 & 51 & 3.75 & 3.77 \\
Isanta T2 & 47 & 3.77 & 4.04 \\
Kibuon K2 & 70 & & .114 \\
Significant & & .462 & \\
\hline
\end{tabular}

Kibuon K2 was ranked first in responses on absence of soil conservation practices contributing to low yields. This showed that many respondents in the sub catchment knew that absence of soil conservation practices contributed to low yields. Isanta T2 was second in the ranking while Kibuon K1 had the least report which implied that a smaller number of respondents knew that absence of soil conservation practices on a farm contributed to low yields. Sub catchments had means ranging from 3.47 to 4.04 which showed that they agreed to the positive statement which was an indication of positive attitude which contributed to implementation of soil conservation practices improving yields. Those who did not implement them had low productivity confirmed by Worku and Tripathi (2015) in their report on watershed management in Highlands of Ethiopia which reported that fertile land for agricultural production was reducing in Ethiopia due to soil erosion following absence of soil conservation practices. This hampered the country from producing enough food for the increasing population which agreed with findings by Govers, Merckx, Wesemael, Van and Oost (2017) in their study on soil conservation in the $21^{\text {st }}$ century who reported soil erosion contributing to imbalances in soil thereby outstripping productivity resulting in decreased yields.

Generally Yields Correspond Positively to Soil Depth

Data collected was subjected to descriptive statistics and the following means and standard deviations were achieved: Kasipul K3 had the highest mean of 3.92 and a standard deviation of .744. Kibuon K2 had a mean of 3.89 and a standard deviation of 0.843 , Kibuon K2 had a mean of 3.89 and a standard deviation of .843, Mogusii T3 had a mean of 3.72 with a standard deviation of 0.759. Isanta $\mathrm{T} 2$ had a mean of 3.55 and a standard deviation of.686, Tende $\mathrm{T} 1$ had a mean of 3.49 and standard deviation of .778 while Kibuon K1 had a mean of 3.20 and standard deviation of 1.082 (Table 163).

Table 14: Means on Yields Correspond Positively to Soil Depth

\begin{tabular}{llll}
\hline Sub catchment & $\mathrm{N}$ & Mean & Standard deviation \\
\hline Kibuon K1 & 15 & 3.20 & 1.082 \\
Kibuon K2 & 70 & 3.89 & .843 \\
Kasipul K3 & 51 & 3.92 & .744 \\
Tende T1 & 148 & 3.49 & .778 \\
Isanta T2 & 47 & 3.55 & .686 \\
Mogusii T3 & 39 & 3.72 & .759 \\
Total & 370 & 3.65 & .808 \\
\hline
\end{tabular}

Further, ANOVA test results indicated that there were significant differences at $F=4.819, \mathrm{p}=0.000$ on the level at which yields correspond positively to soil depth in different sub catchments (Table 164). Multiple comparison presented 4 pairs of sub catchments that were significantly different from each other; Kibuon K2 and Kibuon K1 had significant difference, 686 significant at 0.028, Kibuon K2 was different from Tende T1 with 0.392 mean difference significant at 0.009, Kasipul K3 and Kibuon K1 were significantly different with 0.722 mean difference and 0024 significance while Kasipul K3 was significantly different from Tende T1 with a mean difference of 0.428 mean difference significant at .011 .

Table 15: ANOVA Results on Yields Correspond Positively to Soil Depth

\begin{tabular}{lllll}
\hline Variations & Sum of squares & df & Mean squares & F \\
\hline Between Groups & 14.939 & 5 & 2.989 & 4.819 \\
Within Groups & 225.680 & 364 & .620 & .000 \\
Total & 240.619 & 369 & & \\
\hline
\end{tabular}


Homogenous sub sets were in two columns. Kibuon K1 reported less on yields corresponding to soil depth compared to Tende T1, Isanta T2, Mogusii T3, Kibuon K2 and Kasipul K3. Tende T1 and Isanta T2 were not significantly different to any sub catchment (Table 165).

Table 16: Tukey Post Hoc Analysis Results on Yields Correspond Positively to Soil Depth

\begin{tabular}{llll}
\hline Sub catchment & $\mathrm{N}$ & 1 & 2 \\
\hline Kibuon K1 & 15 & 3.20 & 3.49 \\
Tende T1 & 148 & 3.49 & 3.55 \\
Isanta T2 & 47 & 3.55 & 3.72 \\
Mogusii T3 & 51 & & 3.89 \\
Kibuon K2 & 70 & & 3.92 \\
Kasipul K3 & 51 & .357 & .159 \\
Significant & & & \\
\hline
\end{tabular}

Kasipul K3 had higher responses on yield corresponding positively to soil depth while Kibuon K2 was second. Kibuon K1 had the lowest responses on yields corresponding positively to soil depth. Low mean values for sub catchments indicated that some respondents did not know that yield generally corresponded positively to soil depth. There were high means ranging from 3.20 to 3.92 which indicated positive attitude by agreeing that yield corresponded positively to soil depth which agreed with a study by Hirzel and Matus (2013) in their study on effect of soil depth and increasing fertilization rate on yield and its components which reported that soil depth was found to affect crop yield, the height and number of tillers. Jabro, Stevens, Iversen and Evans ( 2010) in their study on tillage depth effects on soil physical properties reported that tillage depth loosened soil, increased water infiltration and fertilizer placement which contributed to higher yields than crops grown on shallow soils that reduce water infiltration.

Investing in Soil and Water Conservation on the Farm is Important

The following means and standard deviations were attained: Kibuon K2 had a mean of 3.97 and a standard deviation of .868. Kasipul K3 had a mean of 3.84 with a standard deviation of 0.903 . Mogusii T3 had a mean of 3.72 and a standard deviation of 0.857. Tende $\mathrm{T} 1$ had a mean of 3.52 and a standard deviation of 0.884 which was followed by Isanta T2 with a mean of 3.51 and standard deviation of 0.718 . Sub catchment with the least mean was Kibuon K1 with a mean of 3.47 and a standard deviation of 1.060. Many farmers in Kibuon K2 responded positively to investing in soil and water conservation on the farm being important thereby showing their positive attitude towards watershed management technologies (Table 166).

Table 17: Means on Investing in Soil and Water Conservation is Important

\begin{tabular}{llll}
\hline Sub catchment & $\mathrm{N}$ & Mean & Standard deviation \\
\hline Kibuon K1 & 15 & 3.47 & 1.060 \\
Kibuon K2 & 70 & 3.97 & .868 \\
Kasipul K3 & 51 & 3.84 & .903 \\
Tende T1 & 148 & 3.52 & .884 \\
Isanta T2 & 47 & 3.51 & .718 \\
Mogusii T3 & 39 & 3.72 & .857 \\
Total & 370 & 3.67 & .884 \\
\hline
\end{tabular}

ANOVA test results showed that there were significant differences at $\mathrm{F}=3.470, \mathrm{p}=0.004$ on the level at which investing in soil and water conservation was important in different sub catchments (Table 167). Multiple comparisons showed Kibuon K2 and Tende $\mathrm{T} 1$ sub catchment were significantly different (.451 mean difference significant at 0.005 .

Table 18: ANOVA Results on Investing in Soil and Water Conservation is Important

\begin{tabular}{lllll}
\hline Variations & Sum of squares & DF & Mean squares & F \\
\hline Between Groups & 13.108 & 5 & 2.622 & 3.470 \\
Within Groups & 13.108 & 364 & .756 & .004 \\
Total & 288.111 & 369 & & \\
\hline
\end{tabular}

Homogenous sub sets were displayed in one column. Few respondents in Kibuon K1 were aware that investing in soil and water conservation on the farm was important compared to Isanta T2, Tende T1, Mogusii T3, Kasipul K3 and Kibuon K2. The sub catchments had more similarities on importance of investing in soil conservation on the farm which placed them in one column (Table 168).

Table 19: Tukey Post Hoc Results on Investing in Soil and Water Conservation being Important

\begin{tabular}{lll}
\hline Sub catchment & $\mathrm{N}$ & 1 \\
\hline Kibuon K1 & 15 & 3.47 \\
Isanta T2 & 47 & 3.51 \\
Tende T1 & 148 & 3.52 \\
Mogusii T3 & 39 & 3.72 \\
Kasipul K3 & 51 & 3.84 \\
Kibuon K2 & 70 & 3.97 \\
Significant & & .110 \\
\hline
\end{tabular}


There were higher numbers of responses on investment in soil and water conservation being important from respondents in Kibuon K2 followed by respondents in Kasipul K3. Fewer respondents were from Kibuon K1 sub catchment. Means ranged between 3.47 and 3.97 which showed respondents' positive attitude towards investing in soil and water conservation on the farm to be important. Those who had positive attitude invested in soil conservation technologies which controlled soil erosion and improved productivity. This was reported by (Dollinger, Dages, Bailly, Lagacherie and Voltz, 2015) on managing ditches for agro ecological engineering of landscape who reported that through food production agriculture was predisposing land to soil erosion, water pollution and biodiversity reduction which called for control of watershed degradation for continued agricultural production. This was supported by Mutuyimana (2015) in her study no effects of integrated soil and water management on livelihoods in Rwanda who reported increase in agricultural productivity in Rwanda due to .investment in soil conservation on farms.

Property Increase on the Farm through Soil and Water Conservation

Through descriptive statistics the following means and standard deviations were attained; Kasipul K3 sub catchment had the highest mean of 4.04 and a standard deviation of 0.916 . Kibuon K2 sub catchment had a mean of 3.96 with a standard deviation of. 875, Mogusii T3 had a mean of 3.64 and a standard deviation of .873. Tende T1 had 3.55 mean and a standard deviation of 0.868 . Isanta $\mathrm{T} 2$ had a mean of 3.47 and a standard deviation of 0.873 . Kibuon $\mathrm{K} 1$ had a mean of 3.13 with a standard deviation of 1.246 (Table 169).

Table 20: Means on Increase in Property on the Farm via Soil and Water Conservation.

\begin{tabular}{llll}
\hline Sub catchment & $\mathrm{N}$ & Mean & Standard deviation \\
\hline Kibuon K1 & 15 & 3.13 & 1.246 \\
Kibuon K2 & 70 & 3.96 & .875 \\
Kasipul K3 & 51 & 4.04 & .916 \\
Tende T1 & 148 & 3.55 & .868 \\
Isanta T2 & 47 & 3.47 & .873 \\
Mogusii T3 & 39 & 3.64 & .873 \\
Total & 370 & 3.68 & .918 \\
\hline
\end{tabular}

ANOVA test results indicated that there were significant differences at $\mathrm{F}=5.327, \mathrm{p}=.000$ on the level at which property increase on the farm through soil and water conservation in different sub catchments (Table 170). Multiple comparison showed that: Kibuon K2 and Kibuon K1 had .824 mean difference significant at .016, Kibuon K2 and Tende T1 had .410 mean difference significant at .021, Kibuon K2 and Isanta had 0.489 mean difference significant at 0.045, Kasipul and Kibuon K1 had 0.906 mean difference significant at 0.008 and Kasipul K3 and Isanta T2 had 0.571 mean significant at 0.021 . The findings showed that the sub catchments had some differences in their scores in relation to increase in property through investment in soil and water conservation.

Table 21: ANOVA Results on Increase in Property via Soil and Water Conservation

\begin{tabular}{lllll}
\hline Variations & Sum of squares & df & Mean square & F \\
\hline Between Groups & 21.209 & 5 & 4.242 & 5.327 \\
Within Groups & 289.872 & 364 & .796 & 0.000 \\
Total & 311.081 & 369 & & \\
\hline
\end{tabular}

Homogenous sub sets were displayed in two columns. Kibuon K1 reported less increase of property through soil and water conservation compared with Isanta T2 Tende T1 Mogusii T3, Kibuon K2 and Kasipul K3. Isanta T2, Tende T1 and Mogusii T3 were not significantly different from any sub catchment. Kasipul K3 reported high increase of property through soil and water conservation (Table 171).

Table 22: Tukey Post Hoc Results on Increase in Property on the farm via Soil and Water Conservation

\begin{tabular}{llll}
\hline Sub catchment & $\mathrm{N}$ & 1 & 2 \\
\hline Kibuon K1 & 15 & 3.13 & 3.47 \\
Isanta T2 & 47 & 3.47 & 3.55 \\
Tende T1 & 148 & 3.55 & 3.64 \\
Mogusii T3 & 39 & 3.64 & 3.96 \\
Kibuon K2 & 70 & & 4.04 \\
Kasipul K3 & 51 & 0.124 & 0.056 \\
Significant & & & \\
\hline
\end{tabular}

Kasipul K3 had a high number of respondents who reported property increase on the farm through soil and water conservation by improving soil fertility to enhance productivity. Improved productivity would be reflected in high income that could be used to buy assets on the farm. Kibuon K2 was second in reporting on the same variable followed by Mogusii T3 and the last sub catchment was Kibuon K1. The results indicated that some respondents in Kibuon K1 were not aware that investment in soil and water conservation could lead to acquisition of more property on the farm. The mean ranged from 3.13 to 4.04 which showed that many respondents agreed that investment in soil and water conservation led to increased property on the farm which was an indication of positive attitude. The positive attitude encouraged investing in soil conservation practices and improved agricultural productivity. Wolancho (2015) in his study on evaluating watershed management activities in Ethiopia reported that watershed management technologies enhanced ecological and environmental conditions of watersheds. It improved income of the community members who were able to use their income to increase their property on the farm. This was in agreement with 
findings by Tugizimana (2015) in his study on effects of soil and water conservation techniques which reported that soil conservation practices reduced soil erosion, increased soil fertility and improved crop yields which resulted in high maize yields in Ghana that was reflected in improved income which was used to buy and improve on farm implements.

Replacement of Eucalyptus Trees with Agroforestry Trees in the Riparian Areas Contributed to an Increase in Water Levels in Kibuon and Tende Rivers

Through descriptive statistics, different means and standard deviations for the sub catchments were attained. Kibuon K2 had a mean of 3.91 with a standard deviation of 0.794 , Kasipul K3 had a mean of 3.84 with a standard deviation of 0.880 , Isanta T2 had a mean of 3.79 and a standard deviation 0.657 , Tende T1 had a mean of 3.68 with a standard deviation of 0.835 , Mogusii T3 had a mean of 3.64 with a standard deviation of 0.843 . Kibuon K1 had the lowest mean of 3.60 and a standard deviation of 0.910 (Table 172).

Table 23: Means on Replacement of Eucalyptus with Agroforestry trees in Riparian Areas

\begin{tabular}{llll}
\hline Sub catchment & $\mathrm{N}$ & Mean & Standard deviation \\
\hline Kibuon K1 & 15 & 3.60 & .910 \\
Kibuon K2 & 70 & 3.91 & .794 \\
Kasipul K3 & 51 & 3.84 & .880 \\
Tende T1 & 148 & 3.68 & .835 \\
Isanta T2 & 47 & 3.79 & .657 \\
Mogusii T3 & 39 & 3.64 & .843 \\
Total & 370 & 3.75 & .818 \\
\hline
\end{tabular}

The ANOVA test result did no show significant difference at $\mathrm{F}=1.202, \mathrm{p}=.308$ on the level at which replacement of eucalyptus trees were replaced by agroforestry trees in riparian area in different sub catchments (Table 173). Multiple comparisons failed to show sub catchments that were significantly different which implied similarities among sub catchments.

Table 24: ANOVA Results on Replacement of Eucalyptus with Agroforestry Trees in Riparian areas

\begin{tabular}{lllll}
\hline Variations & Sum of squares & Df & Mean square & F \\
\hline Between Groups & 4.014 & 5 & .803 & 1.202 \\
Within Groups & 243.110 & 364 & .668 & .308 \\
Total & 247.124 & 369 & & \\
\hline
\end{tabular}

Homogenous sub sets displayed one level that Kibuon K1 had the lowest report on replacement of eucalyptus trees with agroforestry in riparian areas contributed to increased water levels in Kibuon and Tende rivers while Kibuon K2 had the highest report on replacement of eucalyptus with agroforestry increased water in Kibuon and Tende rivers. Kibuon K1 reported less compared to Mogusii T3, Tende T1, Isanta T2, Kasipul K3 and Kibuon K2 (Table 174).

Table 25: Tukey Post Hoc Results on Replacement of Eucalyptus with Agroforestry Trees in Riparian Areas

\begin{tabular}{lll}
\hline Sub catchment & N & 1 \\
\hline Kibuon K1 & 15 & 3.60 \\
Mogusii T3 & 39 & 3.64 \\
Tende T1 & 148 & 3.68 \\
Isanta T2 & 47 & 3.79 \\
Kasipul K3 & 51 & 3.84 \\
Kibuon K2 & 70 & 3.91 \\
Significant & & .535 \\
\hline
\end{tabular}

Kibuon K2 sub catchment had high number of respondents who agreed that replacement of eucalyptus trees with agroforestry trees in riparian areas would contribute to water levels in Kibuon and Tende rivers. They knew that agroforestry trees do not have high water abstraction like eucalyptus which was planted near rivers and in swamps in the catchments. Kasipul K3 also had a fair level of knowledge on replacement of eucalyptus trees with agroforestry trees in riparian areas would increase water levels in rivers Kibuon and Tende. Kibuon K1 had the least number of responses although the differences were not significant. Most of the respondents interviewed agreed (mean of above 3) that eucalyptus trees should be replaced with agroforestry trees which agreed with (Kenya Forest Service, 2009) in their Guide to on-Farm Eucalyptus Growing in Kenya which indicated that they should not be planted in riparian areas, along rivers within less than 30 metres, on irrigated farms and areas that receive less than $400 \mathrm{~mm}$ of rainfall. This was confirmed by Khonkaen (2011) in his study on use of check dams in Watershed Management in which they determined that when eucalyptus trees were cut down from riparian areas water flow in rivers increased.

A Summary of Sub Catchment Ranks on Farmers' Attitude on Watershed Management Practices

Using Tukey post hoc means, Kibuon K2 was ranked first in column I in three practices. The sub catchment had more responses on respondents' attitude on watershed management practices promoted in the catchments. This showed that many respondents in Kibuon K2 sub catchment had positive attitude towards watershed management practices. In column 2 Kibuon K2 was ranked first in two practices. In column 3 Mogusii T3 was ranked first in three practices while in column 4 Mogusii T3 and Tende T1 were both ranked first in two different practices. In column 5 Tende T1 and Isanta T2 were ranked first each in two different practices. In column 6 Kibuon K1 was ranked first in 4 practices. Kibuon K1 had the least responses on respondents' attitude on 
watershed management practices promoted in the catchments because it was ranked last $\left(6^{\text {th }}\right)$ in four practices. This implied that fewer respondents had positive attitude towards watershed management practices in Kibuon K1 (Table 175).

Table 26: Ranked Levels of Farmers' Attitude on Watershed Management Practices

\begin{tabular}{lllllll}
\hline Variable & 1 & 2 & 3 & 4 & 5 & 6 \\
\hline $\begin{array}{l}\text { Productivity is reducing because of soil } \\
\text { erosion }\end{array}$ & Kibuon K2 & Kibuon K1 & Tende T1 & Mogusii T3 & Kasipul K3 & Isanta T2 \\
$\begin{array}{l}\text { Absence of soil conservation } \\
\text { technologies on the farm contributes to } \\
\text { low yields Kibuon K2 }\end{array}$ & Isanta T2 & Kasipul K3 & Mogusii T3 & Tende T1 & Kibuon K1 \\
$\begin{array}{l}\text { Generally yields correspondent } \\
\text { positively to soil depth }\end{array}$ & Kasipul K3 & Kibuon K2 & Mogusii T3 & Isanta T2 & Tende T1 & Kibuon K1 \\
$\begin{array}{l}\text { Investing in soil and water Kibuon K2 } \\
\text { conservation on your farm is important } \\
\text { Property increase on the farm through } \\
\text { soil and water conservation }\end{array}$ & Kasipul K3 & Kibuon K2 & Mogusii T3 & Tende T1 & Isanta T2 & Kibuon K1 \\
\hline
\end{tabular}

Summary for Sub Catchments on farmers' Attitude on Watershed Management Practices

Data on farmers' attitude on watershed management practices was analyzed and sub catchments attained different positions. Kasipul got position 1 because it appeared in 4 columns. Position 2 was taken by Kibuon K2 which appeared in three columns and Isanta was third by appearing in 3 columns. Tende T1 was 4 because it was ranked in 3 columns. Mogusii T3 was 5 due to appearing in 2 columns while Kibuon $\mathrm{K} 1$ was in position 6 for appearing in 2 columns. The positions were assigned to sub catchments based ranks attained in practices tested on. The ranks ran from 1 (highest) to 6 (the lowest) and were based on means in Tukey post hoc tables. The means indicated differences in the level of attitude on different watershed management practices promoted in the catchments (Table 176). The higher the means the more positive attitude respondents had towards watershed management practices.

Table 27: Summaries for Ranks on Attitude on Watershed Management Practices

\begin{tabular}{lll}
\hline Sub catchment & Ranks attained & Position \\
\hline Kibuon K1 & 2 and 6 & 6 \\
Kibuon K2 & 1,2 and 6 & 2 \\
Kasipul K3 & $1,2,3$ and 5 & 1 \\
Mogusii T3 & 3 and 4 & 5 \\
Isanta T2 & 2,4 and 6 & 3 \\
Tende T1 & 3,4 and 5 & 4 \\
\hline
\end{tabular}

Respondents who Agreed to the Positive Statements on Soil Conservation practices

A frequency table was run on respondents who agreed to the positive statements on soil conservation practices. About 39 percent of the respondents agreed that cover cropping contributed to watershed management. More than half (59.4 percent) of the respondents agreed that terracing controlled runoff speed while 51 percent reported that contour ploughing controlled watershed degradation. Majority of the respondents (70 percent) agreed that check dams controlled soil erosion. Grass strips reduced runoff flow was reported by 52.4 percent. About 71 percent agreed that retention ditches increased infiltration thereby reducing soil erosion. The findings showed that more than half of the respondents agreed that soil conservation practices contributed to watershed management which was an indication of positive attitude (Table 177).

Table 28: Frequency of Respondents who Agreed to the Positive Statements on Soil Conservation Practices

\begin{tabular}{lllllll}
\hline Practices & SD & D & N & A & SA & Total (Agreed) \\
\hline $\begin{array}{l}\text { Cover cropping contributed to watershed } \\
\text { management }\end{array}$ & 1.6 & 8.9 & 50.3 & 27.8 & 11.4 & 39.2 \\
Terracing controlled runoff speed & 1.4 & 7.8 & 31.4 & 43.2 & 16.2 & 59.4 \\
Contour ploughing controlled watershed degradation & 3.8 & 11.1 & 33.8 & 38.4 & 13 & 51.4 \\
Check dams controlled soil erosion & 3.2 & 6.2 & 21.1 & 54.6 & 14.9 & 69.5 \\
Grass strips reduced runoff speed & 3.8 & 10.8 & 33 & 37 & 15.4 & 52.4 \\
Retention ditches increased infiltration & 2.7 & 8.6 & 17.3 & 57 & 14.3 & 71.3 \\
\hline
\end{tabular}

\section{GET PEER REVIEWED}

1. Conclusions should be derived from the findings. They should have supportive information emanating from the findings before they are stated.

2. All tables in the research paper should be formatted using guidelines provided by APA manual. 
The information provided by the peer helped in deriving conclusions by describing how the conclusion was drawn as opposed to stating the conclusion without explaining how it came about.

Formatting of all tables was done according to APA manual

\section{CONCLUSION}

Data analysis indicated different levels based on means in the sub catchments. Responses to test farmers' attitude towards watershed management practices were analyzed and results indicated different levels (1-6 ranks). A frequency table for those who agreed to positive statements on watershed management practices ranged from 39.2 to 71.3 percent. The findings on farmers' attitude towards different watershed management practices and frequency on those who agreed to positive statements on the practices showed various levels with an average mean of 3.00 which indicated positive attitude towards watershed management technologies. It was therefore concluded that respondents in the sub catchments had different levels of positive attitude towards watershed management practices.

\section{ACKNOWLEDGEMENT}

I am grateful to my supervisors: Professor Samson Nyang'au Maobe, Dr. Washington Adede Ochola and Professor Evans Abenga Basweti from the Faculty of Agriculture and Natural Resource Management, Department of Agricultural Education and Extension in Kisii University for their guidance pursuance of this course and development of the research paper.

I would like to appreciate Mrs. Martha Nyang'au from the Department of Agricultural Education and Extension for her contribution and support during course work and proposal development.

I am grateful to Dr. Judith Odhiambo, Dr. Simon Omasaki, and the staff in the School of Agriculture and Natural Resource Management for being available when I needed them.

I feel indebted to Kenya Agriculture and Livestock Research Organization (KALRO) in Kisii and Ministry of Agriculture staff in Homa Bay, Kisii and Nyamira Counties for implementing and providing information on Kibuon and Tende Integrated Watershed Management Project (ILWMKTP) in the study area which was the gist of this study.

I thank all the Sub County Agricultural Officers for availing extension staff for the interview and who provided time and data that were required for this dissertation. Thank you for your dedication and keenness in data provision.

My heartfelt gratitude goes to my husband and children who formed a pillar of encouragement and contributed to completion of this course.

\section{REFERENCES}

[1]. Abebe, S. A. (2018). Review article The impact of soil and water conservation for improved agricultural production in Ethiopia. Journal of Agriculture, 1(1), 9-12. Retrieved from www.pulsus.com\%3Ethe-impa

[2]. Adjaye, A. (2008). Factors affecting adoption of soil and water conservation.pdf. Journal of Agriculture and Resource Economics, 33(1), 99-117. Retrieved from https://ideas.repec.org/ags/jlaare

[3]. Atnafe, A. D., Ahmed, H. M., \& Adane, D. M. (2015). Determinants of adopting techniques of soil and water conservation in Goromti Watershed , Western Ethiopia. Journal of Soil Science and Environmental Management, 6(6), 168-177. https://doi.org/10.5897/JSSEM15.

[4]. Bayard, B., Jolly, C. M., \& Shannon, D. A. (2006). The Adoption and Management of Soil Conservation Practices in Haiti : The Case of Rock Walls. Vol. 7, No. 2, 28-39. Retrieved from www.eng.auth.gr\%3Emattas

[5]. Blinkov, I., Kostadinov, S., \& Marinov, I. T. (2013). Comparison of erosion and erosion control works in Macedonia , Serbia and Bulgaria 1摇 Introduction. International Soil and Water Conservation Research, 1(3), 15-28. https://doi.org/10.1016/S2095-6339(15)30027-7

[6]. Darghouth, S., Ward, C., Gambarelli, G., Styger, E., Roux, J., \& Bank, T. W. (2008). Watershed Management Approaches , Policies , and Operations : Lessons for Scaling Up 2008. Retrieved from https:www.worldbank.org/water

[7]. Dollinger, J., Dagès, C., Bailly, J., Lagacherie, P., \& Voltz, M. (2015). Managing ditches for agroecological engineering of landscape. A review, 999-1020. https://doi.org/10.1007/s13593-015-0301-6

[8]. German, L., Mansoor, H., Alemu, Getachew, Mazengia, W., T., A., \& Stroud, A. (2006). Participatory integrated watershed management: Evolution of concepts and methods in an ecoregional program of the eastern African highlands. Agricultural Systems, 94(2007), 189-204. https://doi.org/10.1016/j.agsy.2006.08.008

[9]. GoK. (2014). Mid-term investment plan: 2013-2017 for Agricultural sector development strategy. Government Printing Press. Retrieved from www.treasury.go.ke

[10]. Govers, G., Merckx, R., Wesemael, B. Van, \& Oost, K. Van. (2017). Soil conservation in the 21st century : why we need smart agricultural intensification. Soil, (3), 45-59. https://doi.org/10.5194/soil-3-45-2017

[11]. Gunya. (2009). Participatory watershed management to decrease land degradation and sediment transport in Kagera and Nyando catchments of Lake Victoria Basin. Masters thesis. Linkoping, Sweden: University of Linkoping. Retrieved from https://www.researchgate.net/publication

[12]. Heiner, K. , Shames, S. \& Spiegel, E. (2016). Integrated landscape management in Kenya: The state of the policy environment. Retrieved from www.academia.edu/INTEGRATED_L

[13]. Hosseini, S. J. F., Daryaei, N., \& Rahnama, A. (2014). Factors Affecting Attitude Change of Bojnourd Township Wheat Farmers toward Participatory Management of Agriculture Water Resources. International Journal of Ecosystem, 4(3), 124-127. https://doi.org/10.5923/j.ije.20140403.04

[14]. Ibido, M. (2015). Adoption of Physical Soil and Water Conservation Structures: The case of Wonago Wreda Gedeo Zone, SNNPR, Ethiopia. Mastrs Thesis, Haramaya, Ethiopia: University of Haramaya. Haramaya. Retrieved from hulirs.haramaya.edu.et/handle

[15]. Jabro, J. D., Stevens, W. B., Iversen, M. W., \& Evans, R. G. (2010). Tillage Depth Effects on Soil Physical Properties , Sugarbeet Yield , and Sugarbeet Quality. https://doi.org/10.1080/00103621003594677

[16]. Junge, B., Deji, O., Abaidoo, R., Chikoye, D., \& Stahr, K. (2009). Farmers' Adoption of Soil Conservation Technologies : A Case Study from Osun State , Nigeria. The Journal of Agricultural Education and Extension, 15(3), 257-274. https://doi.org/10.1080/13892240903069769

[17]. Kenya Forest Service. (2009). A Guide to On-Farm Eucalyptus Growing in Kenya. Retrieved from www.kenyaforestservices.org\%3EE...

[18]. Kerse, B. L. (2018). Factors Affecting Adoption of Soil and Water Conservation Practices in the Case of Damota Watershed, Wolaita Zone, Southern, Ethiopia. International Journal of Agricultural Science Research, 7(1), 001-009. Retrieved from https://academeresearchjournals.org/journal/ijasr

[19]. Khonkaen, P. (2011). The Application of Check Dams Construction to Watershed Management : A case study in the North of Thailand. Journal of Soil and Water Conservation, 43(1), 111-122. Retrieved from swcdis.nchu.edu.tw\%3E

[20]. Kieti, R. N. , Kauti, M., K. \& Kisangau D., P. (2016). Biophysical Conditions and Land Use Methods Contributing to Watershed Degradation in Makueni County, Kenya. Journal of Ecosystem \& Ecography, 6(4), 4-11. https://doi.org/10.4172/2157-7625.1000216

[21]. Kipngeno, A. (2007). Impact of soci-economic factors on adoption of soil and water conservation practices in Kenya: A case study of Kyogong catchment in Bomet Distric, Rift Valley Province. Master Thesis. Nairobi, Kenya: Nairobi University. University of Nairobi. Retrieved from 
erepository.uonbi.ac.ke/handle

[22]. Krejcie, R., \& Morgan, D. (1970). Determing Sample Size for Research Activities. Retrieved from https://home.kku.ac.th/guest_speaker

[23]. Lesch, W. C., \& Wachenheim, C. J. (2014). Factors Influencing Conservation Practice Adoption in Agriculture : A Review of the Literature. Retrieved from http:/agecon.lib.umn.edu/.

[24]. Mainuri, G. and Owino, O. (2016). Linking landforms and land use to land degradation in the Middle River Njoro Watershed. university of Nairobi. Retrieved from http://erepository.uonbi.ac.ke/handle

[25]. Manjunath M. (2014). Adoption of watershed management practices by farmers in sujala watershed project: A study in Chitradurga District of Karnataka. Master Thesis. Bengaluru, India: Bengaluru University. Bengaluru. Retrieved from krishikosh.egranth,ac.in/Thesis

[26]. Manuelli, S., Hofer, T., \& Vita, A. (2014). FAO's Work on Sustainable Mountain Development and Watershed Management. Mountain Research and Development, 34(1), 66-70. Retrieved from https://www.researchgate.net/publication

[27]. Mesfin, A. (2010). Adoption of soil and water conservation structures at farm level:The case of Ambassel District, Amhara Region Ethiopia. Masters Thesis. Haramaya, Thiopia: Haramaya University. Haramaya. Retrieved from hulirs.haramaya.edu.et/bitstream/handle

[28]. Mithun, K. (2013). Perception and adoption of soil and water conservation practices among beneficiaries and non-beneficiaries of Sujala watershed project Northern Karnataka.Masters Thesis, Dharwad, India: Dharwad University. Retrieved from krishikosh.egranth.ac.in/bitsream

[29]. Mondal, B., Singh, A., Singh, S. D., Sinha, M. K., \& Kumar, D. S. (2013). Decomposition of productivity growth in watersheds : A study in Bundelkhand region of Madhya Pradesh , India. Academicjournals, 8(48), 2312-2317. https://doi.org/10.5897/SRE2013.5765

[30]. Mutuyimana, D. (2015). Effects of integrated soil and water management on livelihoods of smallholders in Burega sector, Rulindo district,Northern province, Rwanda. University of Nairobi. Retrieved from erepository.uonbi.ac.ke\%3Ehandle

[31]. Ndeda, P. (2014). Kibuon and Tende Integrated Watershed Management Project (ILWMKTP). Retrieved from https:www.africawaterfacility.org

[32]. Pino, G., Toma, P., Rizzo, C., Miglietta, P. P., \& Peluso, A. M. (2017). Determinants of Farmers ' Intention to Adopt Water Saving Measures : Evidence from Italy. Sustainability, 9(77), 1-14. https://doi.org/10.3390/su9010077

[33]. Rehema, S. (2014). Factors influencing adoption of soil conservation measures, sustainability and socio economic impacts among small-holder farmers in Mbeya rural district Tanzania. Masters Thesis. Sokoine, Tanzania: Sokine University. Retrieved from suaire.suanet.ac.tz/

[34]. Sheikh, M. J., Redzuan, M. B., Samah, A. A., \& Ahmad, N. (2014). Factors Influencing Farmer s' Participation in Water Management: A Community Development Perspective. IOSR Journal of Humanities and Social Sciences (IOSR-JHSS), 19(11), 59-63. Retrieved from www.iosrjournals.org

[35]. Swallow, B., Meinzen-dick, R., \& Onyango, L. (2008). Chapter 10 Catchment Property Rights and the Case of Kenya 'S Nyando Basin. Retrieved from www.fao.org

[36]. Tadesse, M., \& Belay, K. (2004). Factors Influencing Adoption of Soil Conservation Measures in Southern Ethiopia : The Case of Gununo Area. Journal of Agriculture and Rural Development in the Tropics and Subtropics, 105(1), 49-62. Retrieved from www.researchgate.net

[37]. Tamene, L., IKindu, M., Woldearegay, K., \& Aberra, A. (2014). Report of an integrated watershed management and water harvesting training workshop and experience sharing visit in the Ethiopian Highlands. Retrieved from www.africa-rising.net

[38]. Tennyson, L. (2005). Chapter 2 Review and Assesment of Watershed Managent Strategies and Approaches. Retrieved from agris.fao.org\%3Eagrissearch\%3Esearch

[39]. Tugizimana, J. (2015). Effects of Soil and Water Conservation Techniques. Kenyatta University. Retrieved from https://pdfs.semanticscholar

[40]. Wagayehu, B., \& Lars, D. (2015). Adoption of soil and water conservation measures ( SWCM ) by subsistence farmers in the Eastern. Retrieved from https://www.researchgate.net.publication/250457339

[41]. Wisdom, J., Chor, B., Hoagwood, K. \&, \& Horwitz, S. (2013). Innovation Adoption : A Review of Theories and Constructs. https://doi.org/10.1007/s10488013-0486-4

[42]. Wolancho, K. W. (2015). Evaluating watershed management activities of campaign work in Southern nations , nationalities and peoples ' regional state of Ethiopia. Environmental Systems Research, 4(6). https://doi.org/10.1186/s40068-015-0029-y

[43]. Wolka, K., \& Negash, M. (2014). Farme rs' Adoption of Soil and Water Conservation Technology: A Case Study of The Bokole and Toni Sub-Watersheds , Southern Ethiopia. Journal of Science and Development, 2(1), 35-48. Retrieved from www.hu.edu.et/images/pdf/journals

[44]. Worku, T., \& Tripathi, S. K. (2015). Watershed Management in Highlands of Ethiopia: A Review. Open Access Library Journal, 2, 1-11. https://doi.org/10.4236/oalib.1101481

[45]. World Bank. (2016). Integrated land scape management in Kenya: the state of the policy environment, Land and Poverty Conference. Washington DC. Retrieved from www.ecoagriculyure.org

[46]. Zerssa, G. W., Bezabih, B., \& Dinkecha, B. (2017). Assessment of farmers 'perception towards soil and water conservation in Obi Koji Peasant Association , 9(March), 45-52. https://doi.org/10.5897/JENE2017.0625

\section{AUTHORS}

First author - Prof. Evans Basweti, Professor, Kisii University, eabasweti@gmail.com

Second Author - Dr. Washington Adede Ochola, Doctor, Kisii University, Kenya, woadede@gmail.com

Third Author - Prof. Samson Nyang'au Maobe, Kisii University, Kenya, snmaobe@ yahoo.com

Correspondence Author - Catherine Athanasa Mulwale, PhD Candidate, Kisii University, Kenya, cmulwale@ yahoo.com 